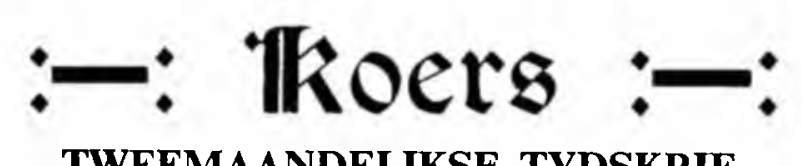

TWEEMAANDELIKSE TYDSKRIF

\begin{tabular}{lll}
\hline Jaargang XXIV & DESEMBER 1956 & No. 3 \\
\hline
\end{tabular}

\title{
'N KONSTRUKTIEF BEDOELDE REAKSIE TEEN SKADELIKE REPRISTINASIES IN ONS REGSOPVATTINGS OP DIE GEBIED VAN STAAT EN KERK
}

$\mathrm{Na}$ aanleiding van opmerkinge van prof. Swanepoel in 'n vorige uitgawe van Koers sowel as na disputasies in onlangse uitgawes van die Gereformeerde Kerkblad, wil ek graag hier in alle beskeidenheid die aandag vestig op wat my opval as skadelike repristinasies in ons sogenaamde burgerlike of wêreldlike (eintlik staatlike) reg en ons gereformeerde kerkreg of liewer in die teorieë daaroor. Repristinasies beteken hier teruggang na of vashouding aan verouderde opvattinge of instellinge in stryd met die wetmatige gang van die historiese beskawingsontwikkeling, en moet uitloop op frustrasie, verwarring en mislukking, net so seer as omgekeerd rewolusie.

Daarom het Nehroe van Indië bv. Gandhi se teruggang na die spinwiel vervang deur 'n poging tot moderne industriële ontwikkeling van sy land. Daarom ook is die republikeinse strewe van ons land nie meer 'n strewe tot presiese herstel van die Boererepublieke van weleer nie.

Tog is daar in ons regsopvattinge nog veelal 'n voortbouing op wat reeds verouderd is, hetsy uit die tyd van Justinianus of de Groot, van die Dortse vaders of Voetius, hetsy van later datum, in plaas van gebruik 
te maak van moderne opvattinge wat by die tyd pas, asook by ons hedendaagse volksomstandighede en wel in die lig van die Heilige Skrif, wat self van alle tye is.

Ons verwys hier veral na die meer ortodokse opvattinge in ons reg sowel op staatlike as op kerklike gebied, nl. onderskeidelik die Romeins-Hollandse rigting en die Dortse kerkregsbeskouinge; nie juis omdat hulle meer as ander in hierdie opsig sondig nie, maar omdat hulle 'n lofwaardige voortbouing op die historiese tradisie onnodiglik verbind met skadelike repristinasies.

Hierdie euwels is op beide gebiede gedeeltelik soortgelyk, omdat hulle gedeeltelik uit dieselfde tydsopvattinge stam, maar ons behandel hulle hier afsonderlik, en wel eers die staatlike en dan die kerklike regsbeskouinge van hierdie soort.

Die Romeins-Hollandse of Romanistiese rigting in die Suid-Afrikaanse staatlike reg, soos veral verteenwoordig aan die Universiteite van Stellenbosch en Pretoria in Suid-Afrika, het reeds uitstekende en noodsaaklike werk verrig, maar dit vertoon tog nog o.a. die volgende verouderdhede.

Allereers skyn die aanhangers hiervan nog nie ten volle na moderne front te besef nie dat in die regsreells regsbeginsels beliggaam is wat voorafgaan aan alle positiewe en neergelegde reg en self nie onderhewig is aan die willekeur van enige regsvormers nie, hoewel hulle gedeeltelik histories wisselend is. Blykbaar vereenselwig hulle so 'n opvatting met die verouderde teorie van 'n vasstaande natuurreg, hoewel dit inderdaad hoogs modern is en ook in ooreenstemming met die Skrifopenbaring.

Ten tweede, en dit is, indien moontlik, van nog meer belang, erken hulle nie dat daar buiten die reg wat deur die staat gevorm word (ons noem dit staatlike reg), baie groter regsgebiede is wat die orde reêl in allerlei samelewingskringe, vanaf elke huisgesin en vereniging ens. vir homself, tot die kerke en allerhande internasionale organisasies, en dat genoemde instellinge en organisasies hierdie reg self vaslê en die staat dit alles slegs erken en handhaaf en desnoods integreer met sy eie reg. Hierdie enge opvatting is 'n verwyderde uitvloeisel van die Romeinse teorie van die staat se juridiese monopolie en selfs almag, maar dit is absoluut onmodern, onbybels en in stryd met die feite.

Ten derde laboreer die Romanisme nog aan 'n onsistematiese indeling selfs van die staatlike reg, wat afkomstig is uit die skema van Justinianus se Institute vir die burgerlike reg, en word nie besef dat alle reg onderhewig is aan 'n soortgelyke indeling wat berus op die struktuur van die reg self 
soos aangepas aan dié van die verskillende sosiale formasies waarbinne dit geld nie.

Ten vierde word die reg nie duidelik in sy eie aard erken nie, maar word dit verstaan in terme van ander wetmatighede van die werklikheid, wat die reg self vervals. Natuurlik hou die reg wel verband met die werklikheid as geheel, want dit is tog 'n reëling van die werklike menslike samelewing. Maar die reg het ook sy eie onherleibare aard waardeur ons dit onderskei van die res van die werklikheid en wat al sy onderdele as sodanig bepaal. 'n Juridiese wil is bv. iets anders as 'n psigiese wil en 'n juridiese oorsaak anders as 'n fisiese oorsaak en juridiese skuld anders as etiese skuld, ens, ens.

Ten slotte, om van ander punte af te sien, erken ook ons Romanisme nog nie voldoende nie dat alle groepsformasies, en veral wat in die reg genoem word regspersone, in die werklikheid as sodanig 'n bestaan het, soos bv. kerke, state, klubs, ens. Veelal word hulle nog beskou as fiksies, personifikasies, ideële entiteite of selfs blote versamelinge van indiwidue, terwyl hulle tog in werklikheid ' $n$ eie, eiesoortige werklike bestaan het, met eie geskiedenis en regte en verpligtinge, volgens eie bestemming.

Graag sou ons op hierdie stadium van elk van bogenoemde beweringe enkele voorbeelde wou gegee het, maar eensdeels sou die redenering dan te tegnies word, en anderdeels hierdie artikel ook te lank.

Laat ons oorgaan tot die kerkreg soos wetenskaplik veral te Potchefstroom voorgedra op grondslag van die Kerkorde van Dordrecht, 1618-9. Hier is die konserwatiewe ortodoksie ook opsetlik, byna nog meer as by die Romanisme, in goeie, maar ook in slegte sin, naamlik, wat laasgenoemde betref, ten opsigte van skadelike repristinasies. En die foute is vir 'n belangrike deel dieselfde-in beide gevalle, maar veral in hierdie laaste sy dit met eerbied gesê!

Nie dat regsbeginsels hier nie erken word nie-inteendeel, hulle word eerder oordryf, in sover as die behoefte aan sistematiese menslike vorming van die beginsels, om regsreëls tot stand te kan bring, grotendeels genegeer word. Daarom is die gebrek aan sisteem hier daarteenoor nog meer opvallend.

Maar ook die Dortisme, hoewel van kerkreg gepraat word, wil tog die kerkorde nie as 'n regstelsel sien nie. Die rede is gedeeltelik afkeer van die Roomse kanonieke kerkreg ens., maar ook die verouderde opvatting dat die eintlike reg dié van die staat is, wat dan sou neerkom op 'n verbesonderde reglementering. Dit word blykbaar nog nie voldoende besef nie 
dat volgens moderne, ook Calvinistiese, opvatting elke lewenskring sy eiesoortige reg ontwikkel heeltemal selfstandig teenoor die staatlike reg, sodat daar dus geen beswaar teen kan wees om ook die kerkorde as 'n regstelsel sin generis te behandel nie.

Dit sou meebring dat ook die regskarakter van die kerkreg beter tot gelding sou kom, natuurlik na sy eie aard as kerkreg, maar dan tog altyd as die reg van die kerk. Die reg immers bring altyd vergelding mee, d.w.s. verbind regsgevolge aan regsgronde, as dit wat moet wees as gevolg van wat feitlik was. Dit kan dus nie net adviseer en vermaan en hoop betuig ens. nie.

Die belangrikste repristinasie egter in ons kerkregtelike opvattinge is die beskouingswyse van die ou individualisme, wat in hierdie geval meebring dat die kerk beskou word as 'n versameling van indiwidue in plaas vas as 'n eiesoortige gesaamlike entiteit, en aan die ander kant dat nie voldoende ingesien word nie dat elke kerklike gemeenskap volgens eie aard en bestemming ook sy eie regsbevoegdheid het wat daaruit voortvloei.

Volgens hierdie nuwer beskouing het ook vanselfsprekend die plaaslike gemeente 'n eie regsbevoegdheid ten opsigte van gemeentelike sake as sodanig, en elke wyer kerklike gemeenskap weer 'n eie regsbevoegdheid volgens wat daaraan gemeenskaplik is. Elk is op eie terrein selfstandig en tog is almal saamverbonde, omdat die gemeenskap in Christus universeel is volgens die kenmerke van die ware kerk. Volgens gereformeerde kerkreg, suiwer Skriftuurlik gesien, word die geïnstitueerde kerk nie gesien as 'n territoriale eenheid met onselfstandige onderdele, en ook nie as 'n saamvoeging van eiemagtige enkelinge of gemeentes nie, maar kom dit tot openbaring in gemeentes met kerkrade in kerkverband, gesaamlik en tegelykertyd: toe Christus die sleutelmag aan die apostels gegee het, was hulle dit alles gesaamlik!

Die Kerk het natuurlik ook sy burgerregtelike en selfs staatsregtelike en volkeregtelike aspekte: ek wil my nou egter tot die suiwer kerkregtelike beperk en omdat 'n hersiening van die gereformeerde kerkorde in vooruitsig is, na aanleiding van bostaande algemene oorweginge, enkele besonderhede aanstip, anders as in die deel oor die staatlike reg, waaroor later miskien meer.

Die kerkorde gaan uit van die algemene sinode en art. 86 wil te kenne gee dat dit algemeen bindend is totdat die sinode self wysiging aanbring. Tog word dit ook aangedui as 'n leidraad. Blykbaar sal dit wenslik wees om duidelik onderskeid te maak tussen bindende bepalinge en dié 
wat net as 't ware reëlend of aanvullend is. Tegelykertyd kan in die algemeen 'n meer sistematiese indeling nagestreef word, in baie opsigte. Dit is tog nie nodig om nou nog in ons Suid-Afrikaanse kerkreg die wanorde te reflekteer wat kenmerkend was van die $17 \mathrm{e}$ eeuse Republiek van die Verenigde Nederlande nie! In hierdie verband behoort ook voorsiening gemaak te word vir inlywing van wysiginge in die kerkorde self, altans van tyd tot tyd.

Met die oog op groter sistematisering en vervollediging van die Kerkorde, sou bv. begin kan word met vas te stel wat die Gereformeerde Kerk in Suid-Afrika is, nl. die verband van alle plaaslike gemeentes in Suidelike Afrika wat saamverbonde is deur die gemeenskaplike aanvaarding van die drie Fomuliere van Eenheid en hierdie Kerkorde.

Dan kan bepaal word wat die strekking van die Kerkorde is, $\mathrm{nl}$. 'n reèling van die inrigting van gemeentes, kerkrade en meerdere vergaderinge en hulle werking in hooftrekke in onderlinge verband.

Vervolgens moet voorgeskryf word hoe gemeentes gestig en ingerig word en ook ontbind of afgesny kan word, met onskrywing van die amp van alle gelowiges, die ander ampte, die funksies ens. van gemeente-vergaderinge en die Kerkraad.

Verder kan dan die sogenaamde meerdere vergaderinge behandel word, waarby veral duideliker uitdrukking gegee moet word aan die groeiende funksies van die Algemene Sinode en sy verskillende deputate, in ooreenstemming met die eise van die tyd en die huidige ontwikkelingsrigting.

Terloops moet ook beter omskrywing gegee word aan die posisie van diakens plaaslik en tussenplaaslik. Op die oomblik word hulle soms by die kerkraad gereken en soms nie. Blykbaar is die beginsel, wat slegs konsekwent deurgevoer moet word, dat hulle lede is van die kerkraad, behalwe wanneer hy sensuur uitoefen, maar wel in alle sake rakende finansies ens. Want hulle funksie is nou nie meer tot barmhartigheid beperk nie, maar gaan ook oor die stoflike onderhoud van die kerk en liefdadigheid aan buitestaanders: die bevestigingsformulier sal dus ook hersien moet word.

Sonder om verder op besonderhede in te gaan, wil hier gepleit word vir 'n deurtastende hersiening van die kerkorde, sodat dit werklik kan dien as grondwet vir die kerk, met inskakeling van al die nodige en uitskakeling van die onnodige. Daarvoor hoef nie afgewyk te word van die bestaande grondbeginsels en hoef ook geen wettisisme ingeloods te word nie. Maar orde sal geskep word in plaas van betreklike chaos en wel na moderne Calvinistiese opvattinge. Slegs sal gewaak moet word teen die invoering van 
staatsregtelike begrippe, soos dié van konfederasie, federasie of unie, van aristokrasie, demokrasie, of iets dergeliks.

In hierdie verband kan dit nuttig wees om die bestaande grondbeginsels van die Gereformeerde kerkordering, vir sover in alle gereformeerde kerke in binne- en buiteland van toepassing, kortliks in die algemeen te beskou in die lig van die moderne Calvinistiese regsleer, toegepas op die kerkreg as onderskeie van alle ander reg, en in besonder van die staatlike reg.

Die belangrikste nuwigheid hiervan, wat egter heeltemal Skriftuurlik is, hoewel dit skerp afwyk van die $17 \mathrm{e}$ eeuse opvattinge, ook onder gereformeerdes, miskien met 'n enkele uitsondering, nl. Althusius (1557-1638), is dat gemeenskappe van mense nie meer beskou word as blote versamelinge van enkelinge nie of as kunsmatige collegia beliggaam in een of ander raad van bestuur nie. Inteendeel, teenswoordig word 'n menslike gemeenskap beskou as 'n eie-soortige sosiale werklikheidsverskynsel met eie struktuur volgens eie aard en bestemming, en met ' $n$ daarby passende eie-soortige, selfgevormde regstelsel, soos reeds tevore kortliks aangedui.

So 'n gemeenskap is ook die algemene Christelike kerk. In die kerkorde het ons egter te doen met die kerk as instituut en wel 'n reeds bestaande instituut, maar hierdie instituut is ook 'n gemeenskap, of liewer 'n kompleks van gemeenskappe of liewer verbande, d.w.s. georganiseerde gemeenskappe.

Daar is in die eerste plek die plaaslike gemeenskap van die gemeente, bestaande uit lede en ampsdraers as 'n eenheid, en in sy funksie beperk tot plaaslike kerkbelange, deur die kerkorde taamlik noukeurig omskryf. Hierdie gemeenskap is egter van die aanvang af saamgeskakel met meer omvangryke gemeenskappe: die kerkorde noem die klassis, die partikuliere sinode en die algemene sinode. Dié is weer beperk tot die kerkbelange van hulle streke, en hulle funksies word minder omvangryk deur die kerkorde bepaal. Maar hulle word in hulle struktuur opgebou deur afvaardiging langs verskillende trappe uit die gemeentes.

Met hierdie stand van sake gaan dit nie aan om die vraag te stel of die gemeente dan wel die ruimere kerkverband meer oorspronklike of selfstandig of gesagdraend is nie. Elk is selfstandig op eie terrein, maar hulle is onderling saamgeskakel. In die gereformeerde kerk kom geen gemeente tot stand sonder medewerking van meerdere vergaderinge nie en omgekeerd kom geen meerdere vergadering tot stand sonder afvaardiging uit die gemeentes nie. So ook het die gemeente bepaalde funksies wat hy selfstandig uitoefen, maar altyd langs riglyne vasgestel deur meerdere vergaderinge. Omgekeerd het die meerdere vergaderinge bepaalde funksies wat hulle self- 
standig uitoefen en wat vir die mindere vergadeninge bindend is, maar altyd handel hulle deur afgevaardigdes van die gemeentes.

Dat die kerkorde bepaal dat een gemeente nie oor 'n ander mag regeer of een ampsdraer oor 'n ander nie, het hiermee niks te doen nie, omdat dit sien op die indiwiduele gemeentes en indiwiduele ampsdraers, Maar klaarblyklik moet die meerdere vergadering, omdat hy gemeenskaplike belange behartig, sover dit daardie gemeenskaplike belange betref, as verband seggenskap hê oor die mindere vergaderinge wat deel in daardie gemeenskaplike belange. Dan regeer die een gemeente nie oor die ander nie, maar die ruimer verband regeer oor die engere, sover dit die ruimer belange betref, en nie verder nie.

Vra ons nou watter belange is enger en watter ruimer, dan gee die kerkorde wel 'n aantal besondere voorskrifte, maar in die algemeen stel hy slegs dat die meerdere vergadering behandel wat vir sy besondere gemeenskap van belang is en wat nie val binne die bevoegdheid van die enger verband nie.

Blykbaar sal dit van die historiese ontwikkeling binne die betrokke gemeenskappe afhang hoeveel belange telkens in die verskillende kringe gemeenskaplik hanteerbaar is, en met die ontwikkeling van verkeer en tegniek sal die gemeenskaplike belange wel al gaande vermeerder, soos ook by ons reeds voldoende geblyk het.

L. J. DU PLESSIS. 